\title{
SOIL STREPTOMYCETES WITH IN VITRO ACTIVITY AGAINST THE YAM PATHOGENS CURVULARIA ERAGROSTIDES AND COLLETOTRICHUM GLOEOSPORIOIDES
}

\author{
Ana Cristina Fermino Soares ${ }^{1 *}$; Carla da Silva Sousa²; Marlon da Silva Garrido²; Jane Oliveira Perez; \\ Nailson Santos de Almeida ${ }^{1}$ \\ ${ }^{1}$ Centro de Ciências Agrárias, Biológicas e Ambientais, Universidade Federal do Recôncavo da Bahia, Cruz das Almas, BA, \\ Brasil; ${ }^{2}$ Pós-Graduação em Ciências Agrárias, Universidade Federal do Recôncavo da Bahia, Cruz das Almas, BA, Brasil
}

Submitted: March 20, 2006; Returned to authors for corrections: June 29, 2006; Approved: October 13, 2006

\begin{abstract}
Yam (Dioscorea cayennensis Lam), an important crop in the Northeastern region of Brazil, is susceptible to the attack of several phytopathogenic fungi, such as Curvularia eragrostides (Henn.) Meyer and Colletotrichum gloeosporioides (Penz.), which cause leaf spot diseases. This work aimed to evaluate the effect of six actinomycete isolates (S. thermotolerans, S. griseus subsp. griseus, Streptomyces sp. N0035, S. purpurascens, and two isolates identified as Streptomyces sp.), as well as the effect of their secondary metabolites, on mycelium growth and spore germination of $C$. eragrostides and $C$. gloeosporioides, from yam plants, cultivar da Costa. Additionally, the chitinolytic activity of these actinomycete strains was determined in a minimum salt growth medium with chitin as the sole carbon source. There was significant interaction between the actinomycete isolates and the phytopathogenic fungi for spore germination and mycelium growth inhibition. Streptomyces sp. codified as AC 26 was more efficient in inhibiting spore germination of $C$. eragrostides, while $S$. thermotolerans and Streptomyces sp. N0035 were more efficient for C. gloeosporioides. Streptomyces sp. (AC 26) was the most efficient in inhibiting mycelium growth of both fungi, and the inhibitory effect was positively correlated to metabolite concentration. S. griseus subsp. griseus did not show chitinolytic activity and did not control mycelium growth of both fungi. The actinomycete strains evaluated in this study can be considered potential biological agents for controlling yam phytopathogenic fungi associated with leaf spot diseases.
\end{abstract}

Key words: Biocontrol, Dioscorea cayennensis, actinomycetes, secondary metabolites

\section{INTRODUCTION}

Yam (Dioscorea cayennensis Lam.) is an important crop in the Northeastern region of Brazil, especially for small family farmers, due to its large potential for exportation and local comercialization. However, Garrido et al. (12) reported that yam productivity is considered low in this region, and the ocorrence of diseases is a major limiting factor for yam production. Moura (21) stated that leaf spot caused by Curvularia eragrostides (Henn.) Meyer is the major yam leaf disease in Brazil, with symptoms characterized by the formation of necrotic brown leaf lesions, frequently surrounded by a yellowish halo.
Colletotrichum gloeosporioides (Penz.) is considered a yam secondary pathogen (21), which causes dark brown leaf lesions with irregular borders and yellowish halo, which may enlarge and coalesce with lesions caused by $C$. eragrostides.

In Brazil, there are no tested and registered fungicides for control of yam leaf spot diseases (1). Compant et al. (5) reported that biological control has been widely studied as an alternative method of controlling plant diseases, since the increasing use of fungicides has caused development of pathogen resistance, problems with environmental pollution, and human and animal health risks. According to Goodfellow and Williams (16), actinomycetes are among the most studied biocontrol agents,

*Corresponding Author. Mailing address: UFRB - Centro de Ciências Agrárias, Biológicas e Ambientais - Campus de Cruz das Almas, cep: 44380-000

- Cruz das Almas, BA - Brasil. Tel.: (75) 3621-2350 ou (75) 3621-2002. E-mail: acsoares@ufba.br 
especially those belonging to the genus Streptomyces, which are worldwide known for the production of antibiotics and bioactive compounds, which act in the control of plant pathogens. The capacity of Streptomyces sp. to control in vitro mycelium growth of Fusarium moniliforme from corn seeds was observed by Bressan and Figueiredo (3). Actinomycetes have also been reported by Cao et al. (4) to control Fusarium oxysporum f. sp. cubense in vitro and in banana plants grown in pots. Paul and Banerjee (24) showed that soluble antibiotics produced by Streptomyces galbus can inhibit spore germination of Alternaria solani, Aspergillus niger, Curvularia pallescense, and Helminthosporium oryzae.

The production of enzymes with antimicrobial activity, also an important characteristic of actinomycetes, has been exploited in several studies with biocontrol of plant pathogens $(6,18,22,23)$. Chitinases produced by several microorganisms are enzymes which can hydrolyze chitin, an oligomeric of $\mathrm{N}$-acetylglicosamine (NAG), which can then be absorbed and metabolized by them $(9,14,15)$. Fridlender et al. (11) stated that chitinase activity is a mechanism of biocontrol of plant pathogenic fungi, since these pathogens have chitin as the major cell wall component and the degradation of fungal hyphae has been associated with the enzymes chitinase and laminarase. Actinomycetes which produce biologically active secondary metabolites, such as chitinase, are promising biocontrol agents.

The present work had the objective of studying the effectiveness of several soil actinomycete strains in inhibiting spore germination and mycelium growth of yam pathogenic fungi $C$. eragrostides and $C$. gloeosporioides.

\section{MATERIALAND METHODS}

\section{Extraction of metabolites produced by the actinomycetes}

Six actinomycete isolates were tested: $S$. thermotolerans, $S$. griseus subsp. griseus, Streptomyces sp. N0035, S. purpurascens, and two isolates identified as Streptomyces sp., with identification codes AC 29, AC 92, AC 95, AC 103, AC 26, and AC 147, respectively. These actinomycetes were isolated from rhizosphere soil of several crops by Lima (19), and have been selected for plant growth promotion $(19,29)$, control of tomato bacteria wilt (19) and control of plant parasitic nematodes (29). The actinomycetes were grown in solid argenine glycerol agar (AGS) culture medium, as described by Poter (25), at $28^{\circ} \mathrm{C}$, for 10 days. After this growth period, $10 \mathrm{ml}$ of distilled sterile water was added aseptically to each Petri dish with the grown actinomycete cultures and the plates were maintained at room temperature $\left(28 \pm 2^{\circ} \mathrm{C}\right)$ for $24 \mathrm{~h}$. The metabolite suspensions obtained from the actinomycete cultures were transferred to 2.0 $\mathrm{ml}$ Eppendorf tubes and centrifuged at $12000 \mathrm{rpm}$ in a microcentrifuge (Model CT 14000 R, Cientec- Brazil), for $15 \mathrm{~min}$. After centrifugation, the supernatant was removed and filtered through a sterile nitrocellulose membrane $(0.22 \mu \mathrm{m}$ porosity $)$, in order to remove the left actinomycete cells and obtain a cell free metabolite suspension. The metabolite suspensions were transferred to small sterile glass bottles and kept at $4^{\circ} \mathrm{C}$.

\section{Spore suspensions from phytopathogenic fungi}

Colletotrichum gloeosporioides and Curvularia eragrostides isolated from yam leaves with leaf spot disease, in the municipality of Cruz das Almas, State of Bahia, Brazil, were transferred to Petri dishes with potato dextrose agar (PDA) and incubated at $28^{\circ} \mathrm{C}$, for eight days. After incubation, $5 \mathrm{ml}$ of sterile distilled water was added to each plate, under aseptic conditions, and the fungus colonies were scrapped with a flamed inoculating loop. The suspension was filtered in cheesecloth and the spore concentration was determined by counting under a microscope with a Neubauer chamber, and was adjusted with sterile distilled water to a final concentration of $10^{5}$ spores. $\mathrm{ml}^{-1}$.

\section{Evaluation of fungi spore germination}

Forty microliters of the metabolite suspension were transferred to a microscope slide with three wells, along with 40 $\mu \mathrm{l}$ of the fungal spore suspension $\left(10^{5}\right.$ spores. $\left.\mathrm{ml}^{-1}\right)$. The microscope slides were incubated at room temperature $\left(28 \pm 2^{\circ} \mathrm{C}\right)$ in a growth chamber prepared with Petri dishes with wet filter paper at the bottom, and covered with plastic wrap. After $14 \mathrm{~h}$ of incubation, spore germination was paralyzed with the addition of one drop of lactophenol blue and a total of 200 spores (germinated and non-germinated) were counted on each slide, under a light binocular microscope (Carl Zeiss Axiostar, Germany) with the 40x objective. Spores which had their germinating tube with a length of at least 50\% greater than the normal spore size were considered germinated. The period of incubation (14 h) was determined based on observations and estimations of the number of spores germinated in the control treatment, for both fungi. The adequate incubation period was considered the time at which the majority of spores from the phytopathogenic fungi had germinated in the control treatment.

The experimental design was completely randomized, in a factorial arrangement $7 \times 2$ (six actinomycete strains + control treatment $x 2$ phytopathogenic fungi), with four replicates. The control treatment was prepared with sterile water instead of the metabolite suspension. The percentage of germinated spores was calculated and the data were transformed in arc sen $\sqrt{x / 100}$, as described by Banzatto and Kronka (2), for mean comparison by the test of Tukey at a level of 5\% probability, with the statistical software SISVAR (8).

\section{Quantification of mycelium growth \\ Effect of metabolites produced by the actinomycetes}

To evaluate the effect of the metabolites produced by the actinomycete strains on mycelium growth of both fungi, an assay was conducted in an entirely randomized experimental design, as described for the spore germination experiment. Ten 
milliliters of the metabolites were transferred to Erlenmeyer flasks with $90 \mathrm{ml}$ of warm melting PDA medium. The growth media with the metabolites was poured into sterile Petri dishes $(20 \mathrm{ml}$ plate $\left.^{-1}\right)$. After solidification of the growth medium, one disc (7 $\mathrm{mm}$ in diameter) of the fungus culture (C. eragrostides or $C$. gloeosporioides), was cut from the borders of an 8 day-old fungus culture grown in PDA at room temperature, and transferred to the center of the plate, which was then, maintained at room temperature. The control treatment consisted of a disc of the fungus culture transferred to the center of a plate with PDA medium without the metabolites. Mycelium growth was daily measured with a ruler. The data were analyzed by the variance analysis (ANOVA) and the test of Tukey, at a level of $5 \%$ probability, with the statistical software SISVAR (8).

\section{Actinomycete antagonistic activity against $C$. eragrostides and C. gloeosporioides}

To evaluate the effect of the actinomycete strains on mycelium growth of the two phytopathogenic fungi, a third assay was conducted with the same experimental design described in the above section. The actinomycetes were transferred to the center of the Petri dishes with PDA, with a flamed inoculating loop, forming a straight line across the plate (Figure 1) and were incubated at room temperature $\left(28 \pm 2^{\circ} \mathrm{C}\right)$, for five days. After this incubation period, two discs $(7 \mathrm{~mm}$ in diameter) of the 8 day-old fungus culture were transferred to both halves of the plate, at a distance of $1.5 \mathrm{~cm}$ from the line of growth of the actinomycete colonies (Figure 1). The fungi were grown as described above. The control treatments consisted of Petri plates with PDA, without the actinomycete cultures, but with the fungus discs transferred to the plates at the same distance as de ones for the other treatments. The assay was incubated at room temperature, and the mycelium growth was daily measured with a ruler, for a period of five days (period in which the fungal cultures from the control treatment reached the plate margins).

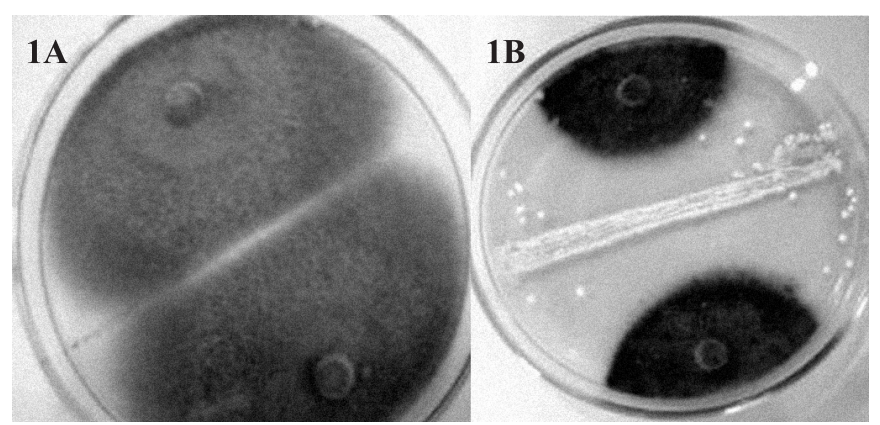

Figure 1. Growth of Colletotrichum gloeosporioides on Potato Dextrose Agar medium without actinomycete (1A) and with Streptomyces sp., isolate AC 26 (1B).
The data were analyzed by the variance analysis (ANOVA) and the test of Tukey at a level of 5\% probability, with the statistical software SISVAR (8).

Evaluation of different concentrations of the metabolite from Streptomyces sp. (AC26) on mycelium growth of both fungi

Another assay was conducted to evaluate four concentrations $(20,40,60$, and $80 \%)$ of the metabolite produced by Streptomyces sp. (AC 26) on mycelium growth of both fungi. Aliquots of 40, 80, 120 and $160 \mathrm{ml}$ of metabolite suspension (prepared as described above) were transferred aseptically to $250 \mathrm{ml}$ volume capacity Erlenmeyer flasks, containing 160, 120, 80 , and $40 \mathrm{ml}$ of warm melting PDA medium, respectively, giving a final volume of $200 \mathrm{ml}$. PDA medium was prepared separately for each treatment, and the nutrient (potato and dextrose) and agar contents were adjusted so that all media had the same nutrient concentration after addition of the metabolite suspension. The control treatment was formed by PDA medium without metabolite suspension. Transfer of fungal culture disc, incubation, measurements and data analyses were conducted as described above for the assay with actinomycete metabolite suspensions.

\section{Actinomycete chitinolytic activity}

The production of chitinase was determined by the methodology described by Padilha (22), in an assay conducted in a completely randomized experimental design with four replicates. The actinomycetes were grown in minimal salt agar medium (25), supplemented with chitin as a sole source of carbon. The cultures were incubated at $28^{\circ} \mathrm{C}$, for ten days. After this period, the chitinolytic activity was detected by the formation of a clear zone (halo) around or underneath the colonies.

\section{RESULTS AND DISCUSSION}

\section{Effect of actinomycete isolates on fungi spore germination}

There was a significant interaction between the actinomycete isolates and the phytopathogenic fungi. For each phytopathogenic fungi, a comparison of the effect of all actinomycete isolates on spore germination showed that metabolites from isolates AC 92, AC 147, AC 26, and AC 95 were efficient in inhibiting spore germination of $C$. eragrostides, while metabolites from AC 95, AC 92, and AC 29 were efficient in inhibiting spore germination of C. gloeosporioides (Figure 2). In addition, a comparison of the effect of metabolites produced by each actinomycete on both fungi, indicated that AC 26 was more efficient in inhibiting spore germination of C. eragrostides, while AC 29 and AC 95 were more efficient for $C$. gloeosporioides (Figure 2). The percentage of germinating spores in the control treatment did not differ for both fungi.

These results indicate that metabolites produced by different actinomycetes can inhibit spore germination of $C$. eragrostides and C. gloeosporioides, the most important phytopathogenic 


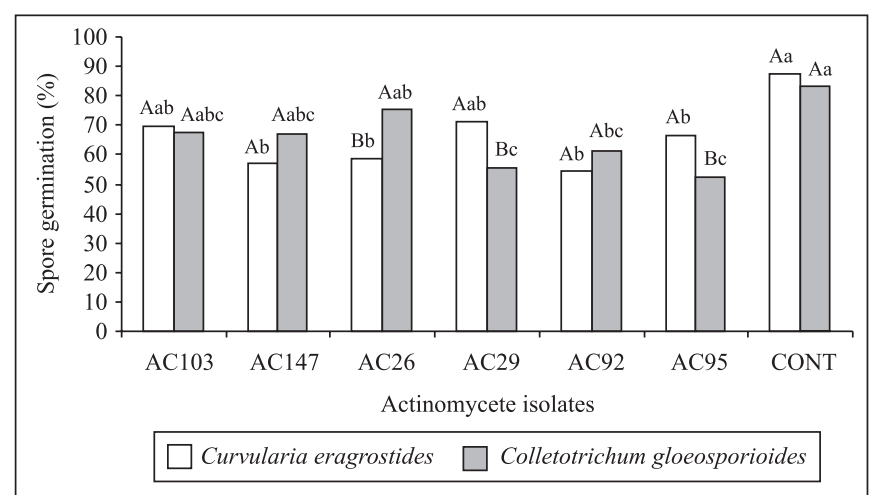

Figure 2. Effect of secondary metabolites produced by actinomycete strains on spore germination of Colletotrichum gloeosporioides and Curvularia eragrostides. Capital letters show a comparison of metabolites produced by the same actinomycete isolate for both fungi, while small letters show the comparison of all actinomycete isolates for the same fungi. Results followed by similar letters do not differ statistically, by Tukey test at 5\% probability. AC 29 - S. thermotolerans; AC 92 - S. griseus subsp. griseus; AC 95 - Streptomyces sp. N0035; AC 103 - S. purpurascens; AC26 and AC 147 - Streptomyces sp. Variation coefficient: 10.71.

fungi that cause yam leaf spots. However, this inhibitory effect differs among the fungi and the actinomycete isolates. According to Marwick et al. (20) and Strzelczyk et al. (30), the production of bioactive secondary metabolites varies with species and growth conditions of the actinomycetes.

In the present work, the metabolites produced by these actinomycetes were not purified and identified. Among the biocontrol mechanisms, the production of secondary metabolites has been considered by many authors as one of the most important, due to their role in the suppression of rhizosphere pathogens $(13,30)$. In vitro tests with metabolites from Streptomyces pulcher and Streptomyces canescens, demonstrated a significant effect in the reduction of spore germination, mycelium growth and sporulation of Fusarium oxysporum f. sp. lycopersici, Verticillium albo-atrum and Alternaria solani, all tomato pathogens (7).

The inhibition of spore germination by secondary metabolites produced by actinomycetes can be considered an important biocontrol mechanism, since spores are the inoculum and the main disseminating pathogen structures, therefore, being an important epidemiologic component of the pathosystems C. eragrostides-yam and C. gloeosporioides-yam.

\section{Effect of actinomycete isolates on mycelium growth of both fungi}

Mycelium growth of $C$. eragrostides and $C$. gloeosporioides was also inhibited by the actinomycete cultures, when grown jointly in PDA medium plates (Figure 1). Interaction between the actinomycete isolates and these phytopathogenic fungi was observed for isolate AC 103, which was able to inhibit mycelium growth of $C$. eragrostides only. Isolate AC 26 was the most efficient in controlling mycelium growth of both fungi (Figure 3 ), with $61.8 \%$ and $59.1 \%$ of mycelium growth reduction for $C$. eragrostides and C. gloeosporioides, respectively, when compared to control treatment.

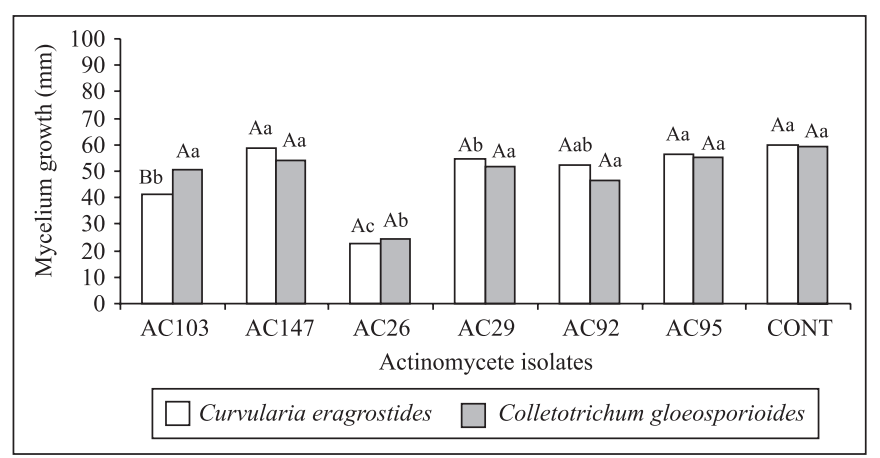

Figure 3. Effect of actinomycete strains on mycelium growth of Colletotrichum gloeosporioides and Curvularia eragrostides, when grown jointly (actinomycete and phytopathogenic fungus) in PDA medium. Capital letters show a comparison of metabolites produced by the same actinomycete isolate for both fungi, while small letters show the comparison of all actinomycete isolates for the same fungi. Results followed by similar letters do not differ statistically, by Tukey test at 5\% probability. AC $29-S$. thermotolerans; AC 92 - S. griseus subsp. griseus; AC 95 Streptomyces sp. N0035; AC 103 - S. purpurascens; AC26 and AC 147 - Streptomyces sp.. Variation coefficient: 11.52

\section{Effect of actinomycete metabolites on mycelium growth of both fungi}

Reduction in mycelium growth was observed for both fungi, when grown in potato dextrose agar medium amended with the metabolite suspensions (Figure 4). Control of mycelium growth was greater for $C$. gloeosporioides, when compared to $C$. eragrostides, for all actinomycetes tested (Figure 4). For $C$. eragrostides, only metabolite suspensions from isolates AC 26 and AC 92 had an inhibitory effect on mycelium growth, while for C. gloeosporioides, mycelium growth inhibition was observed for all tested isolates. These results suggest that $C$. gloeosporioides is more susceptible than $C$. eragrostides to the secondary metabolites produced by these actinomycetes. However, with increasing concentrations of metabolite from isolate AC 26, inhibition of mycelium growth was greater for $C$. eragrostides (Figure 5), suggesting that, with regard to mycelium growth, susceptibility of both phytopathogenic fungi to the 


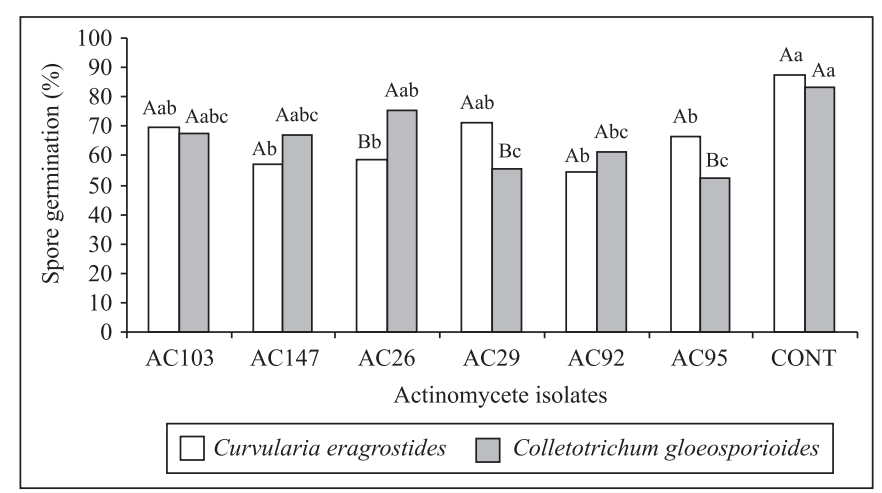

Figure 4. Effect of secondary metabolites produced by actinomycete strains on mycelium growth of Colletotrichum gloeosporioides and Curvularia eragrostides. Capital letters show a comparison of metabolites produced by the same Streptomycete isolate for both fungi, while small letters show the comparison of all Streptomycete isolates for the same fungi. Results followed by similar letters do not differ statistically, by Tukey test at 5\% probability. AC 29 - S. thermotolerans; AC 92 - S. griseus subsp. griseus; AC 95 - Streptomyces sp. N0035; AC 103 - S. purpurascens; AC26 and AC 147 - Streptomyces sp. Variation coefficient: 13.0.

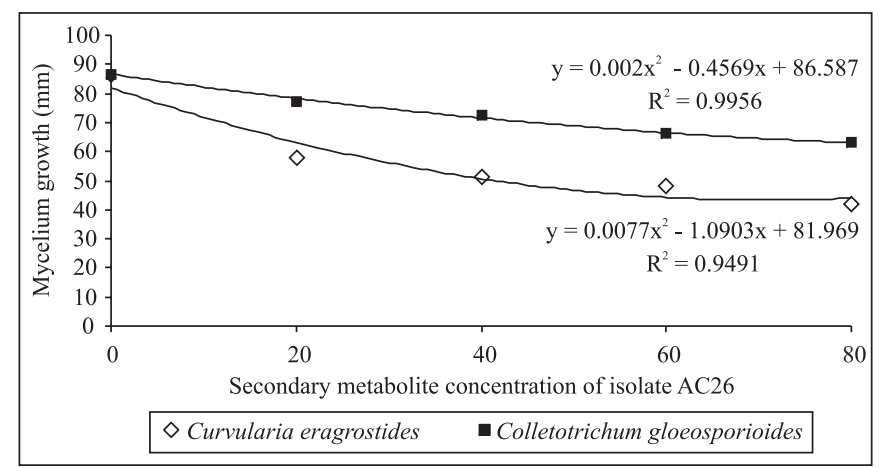

Figure 5. Effect of different concentrations (\%) of secondary metabolite from Streptomyces sp. (isolate AC 26) on mycelium growth of Curvularia eragrostides and Colletotrichum gloeosporioides.

actinomycete isolates is dependent on the concentration of the secondary metabolites produced by these microorganisms.

In addition, for both fungi, control of mycelium growth was positively correlated to the concentrations of the metabolite suspension produced by AC 26 (Figure 5). Isolate AC 26, through its antagonistic activity in growth medium and the production of secondary metabolites, was the most efficient isolate in controlling mycelium growth of both phytopathogenic fungi (Figures 3 and 4). Sirry et al. (28) reported antagonistic activity of different actinomycete species from the rhizosphere of sesame against the soilborne pathogens Fusarium oxysporum and Sclerotium bataticola. A positive correlation between metabolite concentration and percentage of mycelium growth, spore production and germination for Fusarium oxysporum f. sp. lycopersici, Verticillium albo-atrum and Alternaria solani, all tomato pathogens was observed by ELAbyad et al. (7).

Production of chitinase was detected in all actinomycete strains, except for AC 92. Chitinolytic activity could be one of the biocontrol mechanisms of these actinomycetes. Hoster $e t$ al. (17) reported the use of actinomycetes with chitinolytic activity for control of phytopathogenic fungi. Frankowski et al. (10) observed that two chitinolytic enzymes purified from Serratia plymuthica, previously selected as a biocontrol agente of Botrytis cinerea, inhibited spore germination and germ tube elongation of this phytopathogenic fungus.

Isolate AC 92, although efficient in inhibiting spore germination, did not control mycelium growth of $C$. eragrostides and $C$. gloeosporioides, possibly due to the lack of chitinolytic activity. This result suggests that AC 92 may utilize a different biocontrol mechanism for inhibition of spore germination. In the present study, the chitinolytic actinomycete strains were shown to be more efficient in inhibiting mycelium growth. However, the chitinolytic enzymes produced by these actinomycetes were not purified and their role in controlling yam phytopathogenic fungi must be evaluated in future studies. According to Schottel et al. (27), the success of plant pathogens biocontrol may be associated with more than one mechanism of action from the antagonistic microorganism.

The present work demonstrated the in vitro potential of these actinomycetes to control the most important yam pathogenic fungi that cause leaf spots. However, further studies are necessary to evaluate the effect of these potential biocontrol agents in greenhouse and field conditions, and also to purify and characterize the secondary metabolites produced by these actinomycetes.

\section{RESUMO}

\section{Actinomicetos do solo com atividade in vitro contra patógenos do inhame Curvularia eragrostides e Colletotrichum gloeosporioides}

O inhame da Costa (Dioscorea cayennensis Lam.), uma cultura importante na região do nordeste Brasileiro, é suscetível ao ataque de diversos fungos fitopatogênicos, como Curvularia eragrostides (Henn.) Meyer e Colletotrichum gloeosporioides (Penz.), que causam manchas foliares. Este trabalho teve o objetivo de avaliar o efeito de seis isolados de actinomicetos ( $S$. thermotolerans, S. griseus subsp. griseus, Streptomyces sp. N0035, S. purpurascen e dois isolados identificados como 
Streptomyces sp.) e de seus metabólitos secundários no crescimento micelial e na germinação de esporos de $C$. gloeosporioides e C. eragrostides, da cultura do inhame da Costa. Adicionalmente, foi avaliada a atividade quitinolítica desses microrganismos, em meio de sais minerais e ágar, contendo quitina coloidal como única fonte de carbono. Houve interação significativa entre os isolados de actinomicetos e os fungos fitopatogênicos para inibição da germinação de esporos e do crescimento micelial. Streptomyces sp., codificado como AC 26, foi eficiente na inibição da germinação de esporos de $C$. eragrostides, enquanto que $S$. thermotolerans e Streptomyces sp. N0035 foram mais eficientes para C. gloeosporioides. Streptomyces sp. (AC 26) foi o mais eficiente na inibição do crescimento micelial de ambos os fungos e o efeito inibitório aumentou com o aumento na concentração dos metabólitos. $S$. griseus subsp. griseus não apresentou atividade quitinolítica e não inibiu o crescimento micelial de ambos os fungos. Os actinomicetos testados neste trabalho podem ser considerados potenciais agentes de biocontrole de doenças foliares do inhame.

Palavras chave: controle biológico, metabólitos secundários, actinomicetos, Dioscorea cayennensis Lam.

\section{REFERENCES}

1. AGROFIT. 2006. Agrofit-Sistema de Agrotóxicos Fitossanitários Consulta de Praga. Available at: http://www.agricultura.gov.br. Accessed 20 March 2006.

2. Banzatto, D.V.; Kronka, S. do N. (1992). Experimentação agrícola. FCAV/UNESP, Jaboticabal, Brazil.

3. Bressan, W.; Figueiredo, J.E.F. (2003). Controle de Fusarium moniliforme em sementes de milho por actinomicetos. Embrapa Milho e Sorgo, Sete Lagoas, MG, Brazil, n. 65. (Comunicado Técnico).

4. Cao, L.; Qiu, Z.; You, J.; Tan, H.; Zhou, S. (2005). Isolation and characterization of endophytic streptomycete antagonists of Fusarium wilt pathogen from surface-sterilized banana roots. FEMS Microbiol. Lett., 247, 147-152.

5. Compant, S.; Duffy, B.; Nowak, J.; Clément, C.; Barka, E.A. (2005). Use of growth-promoting bacteria for biocontrol of plant diseases: principles, mechanisms of action, and future prospects. Appl. Environm. Microbiol., 71(9), 4951-4959.

6. Crawford, D.L.; Lynch, J.M.; Whipps, J.M.; Ousley, M.A. (1993). Isolation and characterization of actinomycete antagonists of a fungal root pathogen. Appl. Environ. Microbiol., 59, 3899-3905.

7. EL-Abyad, M.S.; EL-Sayed, M.A.; EL- Shanshoury, A.R.; EL-Sabbagh, S.M. (1993). Towards the biological control of fungal and bacterial diseases of tomato using antagonistic Streptomyces spp. Plant Soil., 149, 185-195.

8. Ferreira, D.F. (2000). Análises estatísticas por meio do Sisvar para Windows versão 4.0. Reunião Anual da Região Brasileira da Sociedade internacional de Biometria, São Carlos, São Paulo: p.255-258.

9. Flach, J.; Pilet, P.E. Jolles, P. (1992). What's new in chitinase research? Expert., 48, 90-96.

10. Frankowski, J.; Lorito, M.; Scala, F.; Schmid, R.; Berg, G.; Bahl, H. (2001). Purification and properties of two chitinolytic enzymes of Serratia plymuthica HRO-C48. Arch. Microbiol., 176(6), 421-426.

11. Fridlender, M.; Inbar, J.; Chet, I. (1993). Biological control of soilborne plant pathogens by a b-1,3 glucanase producing Pseudomonas cepacia. Soil Biol. Biochem., 25, 1211-1221.
12. Garrido, M. da S.; Soares, A.C.F.; Mendes, L. do N.; Perez, J.O. (2003). O estudo de novas tecnologias para a produção de inhame no estado da Bahia. Bahia Agrícola, 6, 19-22.

13. Getha, K.; Vikineswary, S.; Wong, W.H.; Seki, T.; Ward, A.; Goodfellow, M. (2005). Evaluation of Streptomyces sp. strain g10 for suppression of Fusarium wilt and rhizosphere colonization in pot-grown banana plantlets. J. Ind. Microbiol. Biotechnol., 32, 24-32.

14. Gooday, G. (1990). The ecology of chitin degradation. Microbiol. Ecol., 10, 387-431.

15. Gooday, G.H.; Zhu, W.Y.; Donnell, R.W. (1992). What are the roles of chitinases in the growing fungus? FEMS Microbiol. Lett., 100, 387-392.

16. Goodfellow, M., Williams, S.T. (1983). Ecology of actinomycetes. Ann. Rev. of Microbiol., 37, 187-216.

17. Hoster, F.; Schmitz, J.E.; Daniel, R. (2005). Enrichment of chitinolytic microorganisms: isolation and characterization of a chitinase exhibiting antifungal activity against phytopathogenic fungi from a novel Streptomyces strain. Appl. Microbiol. and Cell Physiology., 66, 434-442.

18. Locci, R. (1984). Streptomycetes and related genera. In: Williams, S. T.; Sharpe, M.E.; Holt, J.G. (eds). Bergey's manual of systematics bacteriology. Baltimore, Williams \& Wilkins, p.2451-2508.

19. Lima, J.L. (2003). Seleção de actinomicetos para o controle biológico de Ralstonia solanacearum e promoção de crescimento de mudas de tomateiro. Bahia, Brazil, 70p. (M.Sc. Dissertation. Programa de Pós-Graduação em Ciências Agrárias. UFBA).

20. Marwick, J.D.; Wright, P.C.; Burgess, J.G. (1999). Bioprocess intensification for production of novel marine bacterial antibiotics through bioreactor operation and design. Mar. Biotechnol., 1, 495-507.

21. Moura, R.M. (1997). Doenças do inhame (Dioscorea cayennensis Lam. var. Rotundata Poir.). In: Kimati, H.; Amorim, L.; Bergamin Filho, A.; Camargo, L.E.A.; Rezende, J.A.M. (eds). Manual de Fitopatologia. Ceres, São Paulo, Brasil, p.463-471.

22. Padilha, G. (1998). Biologia molecular de Streptomyces e aplicações industriais. In: Melo, I.S. de; Azevedo, J.L. (eds). Ecologia Microbiana. EMBRAPA - CNPMA, Jaguariúna, Brazil, p.327-343.

23. Park, J.O.; Tarabily-EL, K.A.; Ghisalberti, E.L.; Sivasithamparam, K. (2002). Pathogenesis of Streptoverticillium albireticuli on Caenorhabditis elegans and its antagonism to soil-borne fungal pathogens. Lett. Appl. Microbiol., 35, 361-365.

24. Paul, A.K.; Banerjee, A.K. (1986). In vitro effect of antifungal antibiotic produced by Streptomyces galbus $5 \mathrm{ME}-14$. Hindustan Antibiot. 28, 15-19.

25. Poter, J.N.; Wilhelm, J.J.; Tresner, H.D. (1960). Method for the preferential isolation of actinomycetes from soils. Appl. Microbiol. $8,174-178$.

26. Sanglier, J.J.; Haag, H.; Huck, T.A.; Fehr, T. (1993). Novel bioactive compounds from actinomycetes: a short review (1988-1992). Res. Microbiol., 144, 633-642.

27. Schottel, J.L.; Schimizu, K.; Kinkel, L.L. (2001). Relationships of in vitro pathogen inhibition and soil colonization to potato scab biocontrol by antagonistic Streptomyces spp. Biol. Control., 20 , 102-112.

28. Sirry, A.R.; Salem, S.H.; Zayed, M.A.; Anwar, D. (1981). Rhizosphere microflora of some plants infected with root-rot disease and their activities on antagonizing the main pathogen. Egypt J. Microbiol., $16,65-78$.

29. Sousa, C. da S. (2006). Estreptomicetos promotores de crescimento e agentes de biocontrole da meloidoginose no tomateiro. Bahia, Brazil, 102p. (M.Sc. Dissertation. Programa de Pós-Graduação em Ciências Agrárias. UFBA).

30. Strzelczyk, E.; Gorlach, K.; Rozychi, H. (1990). Chitinolytic and proteolytic activity of streptomycetes isolated from root-free soil, rhizosphere and mycorrhizosphere of pine (Pinus sylvestris L.). Biol. Fertil. Soils., 9, 268-272. 